\title{
Surface Sterilization Protocol for Nodal and Inter Node Explants of Kankoda (Momordica dioica Roxb.)
}

\author{
S. S. Dodake ${ }^{1}$ A. S. Jadhav², S. V. Pawar ${ }^{2}$ and N. M. Magar ${ }^{2 *}$ \\ ${ }^{1}$ Wheat Specialist, Agricultural Research Station, MPKV, Niphad, India \\ ${ }^{2}$ State Biotechnology Unit, Department of Agril Botany, PGI, MPKV, Rahuri, India \\ *Corresponding author
}

Keywords

Kankoda,

Momordica dioica

Article Info

Accepted:

18 November 2020

Available Online:

10 December 2020

\begin{abstract}
A B S T R A C T
To standardize the sterilization procedure for nodal segment and internodes explants of female Kankoda. Comparison was done between two important sterilizing agents, mercuric chloride $(0.1 \%)$ and sodium hypochlorite $(1 \%)$ with four time duration $3,5,7$ and 10 minutes and in combinations. Result showed that amongst the two sterilants i.e. $\mathrm{HgCl}_{2}$ and $\mathrm{NaOCl}$ in combination was found better for controlling the infection. Mercuric chloride $\left(\mathrm{HgCl}_{2}\right)$ for 5 minute and sodium hypochlorite $(\mathrm{NaOCl})$ for 5 minute in combination was selected for suitable sterilization agents after 10 minute of DDW wash, 10 minute dip in bavistin and at last washed with double distilled water for nodal segments (83.33\% survival) and internodes segments ( $83.33 \%$ survival) explants of Kankoda. This is the first report of successful sterilization and reduced contamination of explants from naturally field grown Kankoda by using $\mathrm{HgCl}_{2}$ and $\mathrm{NaOCl}$ sterilizing agents in combination for standardizing efficient in vitro surface sterilization protocol.
\end{abstract}

\section{Introduction}

Spine gourd or Teasle gourd or Kankoda belongs to the family Cucurbitaceae and under the genus Momordica. Momordica genus (annual or perennial climbers) contains about 80 species (Raj et al., 1993). This genus is native of tropical regions of Asia with extensive distribution in China, South East Asia, Japan, Polynesia besides tropical Africa and South America. As many of the species of this genus have been found to grow wildly in India, Bangladesh, Sri Lanka, Myanmar, Malaysia, etc. (Hooker, 1879) it indicated that this region might be the origin of Momordica dioica. The genus Momordica possesses different sex forms (monoecious, dioecious, hermaphrodite) and $\mathrm{x}=14$ basic chormosome number. Kankoda, $M$. dioica Roxb. $(2 \mathrm{n}=2 \mathrm{x}$ $=28$ ) and its wild relative, $M$. cochinchinensis Spreng. $(2 \mathrm{n}=4 \mathrm{x}=56)$ are dioecious and mainly propagate vegetatively through tuberous root (Rashid, 1993). Both the species are perennial, tuberous rooted but differ in their stem, leaf, fruit and seed characters.

It grows in warm and humid weather and tuberous roots are planted in pits. It is an important vegetable in the Indian subcontinent and Bangladesh. It has many 
advantages, like high market price, good nutritional value and longer keeping quality. The tender green fruits of Kankoda are used for culinary purpose. Sometimes fruits are sliced, blanched and dried for further use. In some parts, the young tender leaves are used as vegetable. Besides being a vegetable, the seeds of Kankoda yield oil which can be used as an illuminant and also as an admixture with drying oils in formulation of paints and varnishes.

The plant was reported to exhibit antidiabetic, anti-cancer, anti-fertility abortificiant, anti-inflammatory, antioxidant activity, cure jaundice and bleeding pile properties (Bawara et al., 2010). Owing to its multifold uses, its systematic cultivation would be a boon both for horticulture as well as pharmaceutical industry especially in tropical countries like India. Fruits contain high amounts of protein, calcium, phosphorous, iron, and highest amount of carotene amongst the cucurbitaceous vegetables (Bharathi et al., 2007).

It is mainly propagated by tubers. Propagation by seeds and cuttings is not very common. However, tuberous roots have got dormancy and they sprout only at onset of monsoon. Moreover, the multiplication rate of tubers is very low. Due to lack of technical know-how, the success of rooting of cuttings is very low. Hard and impermeable seed coat possesses problem in germination of seeds in Kankoda. Similarly, sex prediction of seed propagated plant is very difficult before flowering because of dioecious and highly cross pollinated nature.

So far not much systematic efforts have been made to overcome the above problems and crop remained underutilized/neglected from research point of view. Systematic approach can result into some solutions to overcome these problems. Also the natural population of the plant is gradually decreasing due to habitat destruction and hence, conservation of this crop biodiversity is necessary.

The improvement of $M$. dioica through conventional breeding techniques has several limitations hence for successful application of plant tissue culture for large scale propagation of Kankoda, which requires an efficient explants sterilization system. Therefore, the present investigation was aimed with to develop an efficient explants sterilization protocol in Kankoda.

\section{Materials and Methods}

The Kankoda female genotype was collected from AICRN on Potential Crops and present study was carried out at State Level Biotechnology Centre, Department of Agricultural Botany, MPKV, Rahuri during kharif 2014-15. This single genotype of Kankoda was taken for regeneration. The two explants namely, nodal segments and internodes explants of female genotype were used for this experiment. These explants were collected from 45 days old plants after sprouting in the field.

\section{Chemicals}

Various chemicals of Qualigens Laboratory Pvt. Ltd were used for media preparation and sterilization of explants. Organic supplements like myoinositol were also used.

\section{Cleaning of glassware's}

It is important to use cleaned glassware for growth of tissue culture in vitro. This was achieved by boiling all glassware's in liquid soap solution for 1 hour, followed by thoroughly rinsing with tap water and immersing in nitric acid (30\%) for 2 hours and then removing traces of acid by thoroughly washing with tap water. Then 
glassware's were rinsed with double distilled water and they were allowed to dry overnight at room temperature.

Sterilization of media, glassware and instruments

The object of sterilization was to make media, glassware and instruments free from microorganisms. For this, glassware such as conical flasks, test tubes, glass bottle etc., were plugged with non-absorbent cotton. Then petri dishes were wrapped with wrapping paper (aluminum foil). Forceps and scalpels were covered with brown paper. Afterwards the mouth ends of graduated pipettes were plugged with non-absorbent cotton. Individually they were wrapped with wrapping paper. All glassware and instruments were then autoclaved at $121^{\circ} \mathrm{C}$ and $15 \mathrm{lbs}$ pressure for 20 minutes. Finally they were kept in hot air oven for drying.

\section{Preparation of stock solutions}

It was found convenient to prepare the concentrated stock solutions of macro and micro nutrients, vitamins and plant growth regulators. The media used was Murashige and Skoog's (MS media).

\section{Surface sterilization}

Sterilization procedure was carried out in three steps. In primary sterilization, all explants were washed with double distilled water for 10 minutes. In secondary sterilization, all the explants were treated with $0.1 \%$ bavistin concentration for 10 minutes and washed with double distilled water for 10 minutes. In tertiary sterilization, Mercuric chloride $(0.1 \%)$ and Sodium hypochlorite (1\%) were used for study with treatment durations of 3, 5, 7 and 10 minutes with all possible combinations and alone were used and all explants were washed with double distilled water for 10 minutes after every treatment for complete removing of traces of chemicals.

To evaluate the response of different chemicals, implantations of sterilized explants were done using without hormones MS medium. The cultures were placed in culture growth room. The cultures were kept in a growth chamber for one month, at $25^{\circ} \mathrm{C}$, with 16 hours photoperiod and $3500 \mathrm{~lx}$ of light intensity. The observations were recorded up to 30 days. Twelve explants were used in each sterilization treatment, and each treatment was replicated thrice. The observations were recorded in percentage. The effect of surface sterilizing treatments $i$. $e$. infection per cent, dead per cent and survival per cent of cultures.

\section{Cultural conditions}

All the cultural operations including sterilization, inoculation and transfer were carried out in a horizontal laminar air flow chamber using sterilized instruments. Before inoculation, the chamber was smeared with $70 \%$ ethyl alcohol and exposed to UV light for 15-20 minutes. The cultured tubes/bottles after inoculation were incubated under dark at $25 \pm 1^{\circ} \mathrm{C}$.

\section{Data analysis}

All the studies were done in laboratory under well defined conditions of the medium, growth, temperature and light. Completely Randomized Design (CRD) was employed for the experiment and the data were analyzed in SAS (Statistical analysis system).

\section{Results and Discussion}

In primary sterilization, all explants were washed with double distilled water for 10 minutes. In secondary sterilization, all the 
explants were treated with $0.1 \%$ bavistin concentration for 10 minutes and washed with double distilled water for 10 minutes. In tertiary sterilization, mercuric chloride $(0.1 \%)$ and sodium hypochlorite $(1 \%)$ were used for study with duration of 3, 5, 7 and 10 minutes with all possible combinations and alone and all explants were washed with double distilled water for 10 minutes for removal of chemical traces (Fig. 1 and 2; Table 1 and 2).

Table.1 Percentage of contamination, percentage of non grown culture and percentage of survival in nodal segment explants after sterilization using various concentrations of sterilizing agents for different time duration

\begin{tabular}{|c|c|c|c|c|c|c|}
\hline SN & $\begin{array}{c}\text { Treatm } \\
\text { ents }\end{array}$ & Treatment details & $\begin{array}{l}\text { Time } \\
\text { (min.) }\end{array}$ & $\begin{array}{c}\text { Contamination } \\
\text { in nodal } \\
\text { explants }(\%)\end{array}$ & $\begin{array}{l}\text { Non-grown } \\
\text { cultures or \% } \\
\text { death in nodal } \\
\text { explants }\end{array}$ & $\begin{array}{c}\text { Survival \% in } \\
\text { inter nodal } \\
\text { explants }\end{array}$ \\
\hline 1 & S1 & Control (DDW washing) & 10 & $100.00(90.00)$ & $0.00(0.00)$ & $0.00(0.00)$ \\
\hline 2 & S2 & DDW + Bavistin $0.1 \%$ & $10+10$ & $100.00(90.00)$ & $0.00(0.00)$ & $0.00(0.00)$ \\
\hline 3 & S3 & $\mathrm{DDW}+$ Bavistin $0.1 \%+\mathrm{HgCl}_{2} 0.1 \%$ & $10+10+3$ & $100.00(90.00)$ & $0.00(0.00)$ & $0.00(0.00)$ \\
\hline 4 & S4 & $\mathrm{DDW}+$ Bavistin $0.1 \%+\mathrm{HgCl}_{2} 0.1 \%$ & $10+10+5$ & $91.68(73.23)$ & $0.00(0.00)$ & $8.33(16.77)$ \\
\hline 5 & S5 & $\mathrm{DDW}+$ Bavistin $0.1 \%+\mathrm{HgCl}_{2} 0.1 \%$ & $10+10+7$ & $66.65(54.73)$ & $0.00(0.00)$ & $33.35(35.27)$ \\
\hline 6 & S6 & $\mathrm{DDW}+$ Bavistin $0.1 \%+\mathrm{HgCl}_{2} 0.1 \%$ & $10+10+10$ & $0.00(0.00)$ & $33.33(35.26)$ & $66.67(54.74)$ \\
\hline 7 & S7 & DDW + Bavistin $0.1 \%+\mathrm{NaOCl} 1.0 \%$ & $10+10+3$ & $100.00(90.00)$ & $0.00(0.00)$ & $0.00(0.00)$ \\
\hline 8 & S8 & $\mathrm{DDW}+$ Bavistin $0.1 \%+\mathrm{NaOCl} 1.0 \%$ & $10+10+5$ & $66.65(54.73)$ & $0.00(0.00)$ & $33.35(35.27)$ \\
\hline 9 & S9 & DDW + Bavistin $0.1 \%+\mathrm{NaOCl} 1.0 \%$ & $10+10+7$ & $5.55(11.18)$ & $19.45(26.07)$ & $75.00(60.00)$ \\
\hline 10 & S10 & DDW + Bavistin $0.1 \%+\mathrm{NaOCl} 1.0 \%$ & $10+10+10$ & $0.00(0.00)$ & $66.68(54.74)$ & $33.33(35.26)$ \\
\hline 11 & S11 & $\begin{array}{l}\mathrm{DDW}+\text { Bavistin } 0.1 \%+\mathrm{HgCl}_{2} 0.1 \%+ \\
\mathrm{NaOCl} 1.0 \%\end{array}$ & $10+10+3+3$ & $66.65(54.73)$ & $0.00(0.00)$ & $33.35(35.27)$ \\
\hline 12 & S12 & $\begin{array}{l}\mathrm{DDW}+\text { Bavistin } 0.1 \%+\mathrm{HgCl}_{2} 0.1 \%+ \\
\mathrm{NaOCl} 1.0 \%\end{array}$ & $10+10+3+5$ & $50.00(45.00)$ & $0.00(0.00)$ & $50.00(45.00)$ \\
\hline 13 & S13 & $\begin{array}{l}\text { DDW + Bavistin } 0.1 \%+\mathrm{HgCl}_{2} 0.1 \%+ \\
\mathrm{NaOCl} 1.0 \%\end{array}$ & $10+10+3+7$ & $0.00(0.00)$ & $33.33(35.26)$ & $66.68(54.74)$ \\
\hline 14 & S14 & $\begin{array}{l}\mathrm{DDW}+\text { Bavistin } 0.1 \%+\mathrm{HgCl}_{2} 0.1 \%+ \\
\mathrm{NaOCl} 1.0 \%\end{array}$ & $10+10+3+10$ & $0.00(0.00)$ & $75.00(60.00)$ & $25.00(30.00)$ \\
\hline 15 & S15 & $\begin{array}{l}\mathrm{DDW}+\text { Bavistin } 0.1 \%+\mathrm{HgCl}_{2} 0.1 \%+ \\
\mathrm{NaOCl} 1.0 \%\end{array}$ & $10+10+5+3$ & $66.65(54.73)$ & $0.00(0.00)$ & $33.35(35.27)$ \\
\hline 16 & S16 & $\begin{array}{l}\mathrm{DDW}+\text { Bavistin } 0.1 \%+\mathrm{HgCl}_{2} 0.1 \%+ \\
\mathrm{NaOCl} 1.0 \%\end{array}$ & $10+10+5+5$ & $0.00(0.00)$ & $16.67(24.10)$ & $83.33(65.90)$ \\
\hline 17 & S17 & $\begin{array}{l}\mathrm{DDW}+\text { Bavistin } 0.1 \%+\mathrm{HgCl}_{2} 0.1 \%+ \\
\mathrm{NaOCl} 1.0 \%\end{array}$ & $10+10+5+7$ & $0.00(0.00)$ & $50.00(45.00)$ & $50.00(45.00)$ \\
\hline 18 & S18 & $\begin{array}{l}\text { DDW + Bavistin } 0.1 \%+\mathrm{HgCl}_{2} 0.1 \%+ \\
\mathrm{NaOCl} 1.0 \%\end{array}$ & $10+10+5+10$ & $0.00(0.00)$ & $91.68(73.23)$ & $8.33(16.77)$ \\
\hline 19 & S19 & $\begin{array}{l}\mathrm{DDW}+\text { Bavistin } 0.1 \%+\mathrm{HgCl}_{2} 0.1 \%+ \\
\mathrm{NaOCl} 1.0 \%\end{array}$ & $10+10+7+3$ & $16.65(24.08)$ & $41.68(40.21)$ & $41.67(40.20)$ \\
\hline 20 & S20 & $\begin{array}{l}\mathrm{DDW}+\text { Bavistin } 0.1 \%+\mathrm{HgCl}_{2} 0.1 \%+ \\
\mathrm{NaOCl} 1.0 \%\end{array}$ & $10+10+7+5$ & $0.00(0.00)$ & $72.23(58.25)$ & $27.78(31.75)$ \\
\hline
\end{tabular}


Int.J.Curr.Microbiol.App.Sci (2020) 9(12): 2907-2915

\begin{tabular}{|c|c|c|c|c|c|c|}
\hline 21 & S21 & $\begin{array}{l}\text { DDW + Bavistin } 0.1 \%+\mathrm{HgCl}_{2} 0.1 \% \\
+ \text { NaOCl } 1.0 \%\end{array}$ & $10+10+7+7$ & $0.00(0.00)$ & $100.00(90.00)$ & $0.00(0.00)$ \\
\hline 22 & S22 & $\begin{array}{l}\text { DDW + Bavistin } 0.1 \%+\mathrm{HgCl}_{2} 0.1 \% \\
+\mathrm{NaOCl} 1.0 \%\end{array}$ & $10+10+7+10$ & $0.00(0.00)$ & $100.00(90.00)$ & $0.00(0.00)$ \\
\hline 23 & S23 & $\begin{array}{l}\text { DDW + Bavistin } 0.1 \%+\mathrm{HgCl}_{2} 0.1 \% \\
+\mathrm{NaOCl} 1.0 \%\end{array}$ & $10+10+10+3$ & $0.00(0.00)$ & $83.34(65.91)$ & $16.66(24.09)$ \\
\hline 24 & S24 & $\begin{array}{l}\mathrm{DDW}+\text { Bavistin } 0.1 \%+\mathrm{HgCl}_{2} 0.1 \% \\
+\mathrm{NaOCl} 1.0 \%\end{array}$ & $10+10+10+5$ & $0.00(0.00)$ & $91.68(73.23)$ & $8.33(16.77)$ \\
\hline 25 & S25 & $\begin{array}{l}\mathrm{DDW}+\mathrm{Bavistin} 0.1 \%+\mathrm{HgCl}_{2} 0.1 \% \\
+\mathrm{NaOCl} 1.0 \%\end{array}$ & $10+10+10+7$ & $0.00(0.00)$ & $100.00(90.00)$ & $0.00(0.00)$ \\
\hline \multirow[t]{7}{*}{26} & S26 & $\begin{array}{l}\mathrm{DDW}+\text { Bavistin } 0.1 \%+\mathrm{HgCl}_{2} 0.1 \% \\
+\mathrm{NaOCl} 1.0 \%\end{array}$ & $10+10+10+10$ & $0.00(0.00)$ & $100.00(90.00)$ & $0.00(0.00)$ \\
\hline & & & Minimum & 0.00 & 0.00 & 0.00 \\
\hline & & & Maximum & $100.00(90.00)$ & 100.00 & 83.33 \\
\hline & & & Mean & $31.94(28.17)$ & 36.59 & 26.08 \\
\hline & & & $\mathrm{SE} \pm$ & $0.54(1.10)$ & 0.53 & 0.34 \\
\hline & & & $\mathrm{CD}$ at $5 \%$ & $1.54(3.11)$ & 1.50 & 0.98 \\
\hline & & & CV\% & $2.95(6.74)$ & 2.49 & 2.28 \\
\hline
\end{tabular}

Table. 2 Percentage of contamination, percentage of non grown culture and percentage of survival in inter-node segment explants after sterilization using various concentrations of sterilizing agents for different time duration

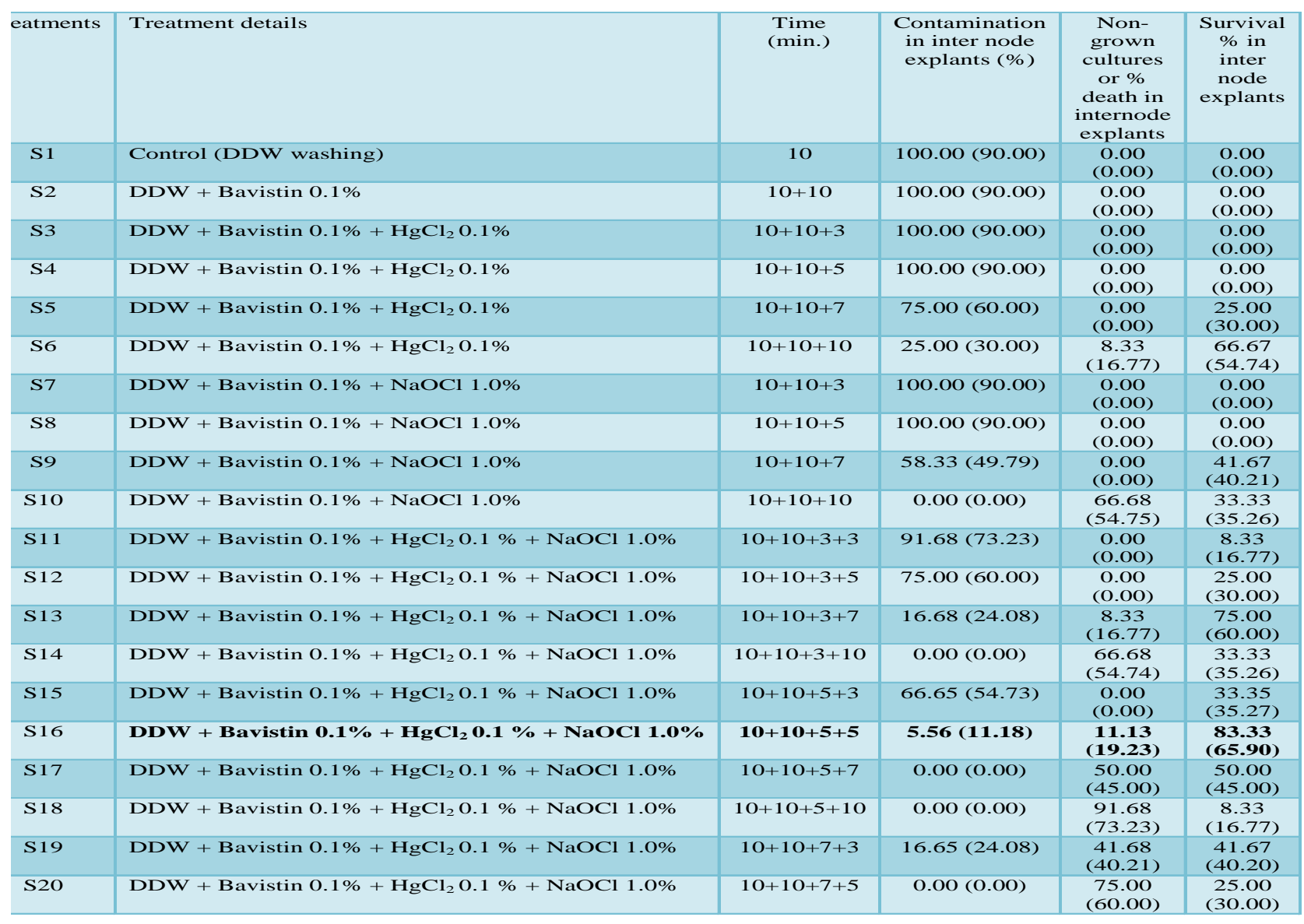




\begin{tabular}{|c|c|c|c|c|c|c|}
\hline 21 & S21 & DDW + Bavistin 0.1\% + $\mathrm{HgCl}_{2} \mathbf{0 . 1} \%+\mathrm{NaOCl} 1.0 \%$ & $10+10+7+7$ & $0.00(0.00)$ & $\begin{array}{c}94.45 \\
(78.82)\end{array}$ & $\begin{array}{c}5.55 \\
(11.18)\end{array}$ \\
\hline 22 & S22 & $\mathrm{DDW}+$ Bavistin $0.1 \%+\mathrm{HgCl}_{2} 0.1 \%+\mathrm{NaOCl} 1.0 \%$ & $10+10+7+10$ & $0.00(0.00)$ & $\begin{array}{l}100.00 \\
(90.00)\end{array}$ & $\begin{array}{c}0.00 \\
(0.00)\end{array}$ \\
\hline 23 & $\mathrm{~S} 23$ & DDW + Bavistin $0.1 \%+\mathrm{HgCl}_{2} 0.1 \%+\mathrm{NaOCl} 1.0 \%$ & $10+10+10+3$ & $0.00(0.00)$ & $\begin{array}{c}100.00 \\
(90.00)\end{array}$ & $\begin{array}{c}0.00 \\
(0.00)\end{array}$ \\
\hline 24 & S24 & $\mathrm{DDW}+$ Bavistin $0.1 \%+\mathrm{HgCl}_{2} 0.1 \%+\mathrm{NaOCl} 1.0 \%$ & $10+10+10+5$ & $0.00(0.00)$ & $\begin{array}{l}100.00 \\
(90.00)\end{array}$ & $\begin{array}{c}0.00 \\
(0.00)\end{array}$ \\
\hline 25 & S25 & $\mathrm{DDW}+$ Bavistin $0.1 \%+\mathrm{HgCl}_{2} 0.1 \%+\mathrm{NaOCl} 1.0 \%$ & $10+10+10+7$ & $0.00(0.00)$ & $\begin{array}{l}100.00 \\
(90.00)\end{array}$ & $\begin{array}{c}0.00 \\
(0.00)\end{array}$ \\
\hline \multirow[t]{7}{*}{26} & S26 & $\mathrm{DDW}+$ Bavistin $0.1 \%+\mathrm{HgCl}_{2} 0.1 \%+\mathrm{NaOCl} 1.0 \%$ & $\begin{array}{c}10+10+10+1 \\
0\end{array}$ & $0.00(0.00)$ & $\begin{array}{l}100.00 \\
(90.00)\end{array}$ & $\begin{array}{c}0.00 \\
(0.00)\end{array}$ \\
\hline & & & Minimum & 0.00 & 0.00 & 0.00 \\
\hline & & & Maximum & $\begin{array}{l}100.00 \\
(90.00)\end{array}$ & 100.00 & 83.33 \\
\hline & & & Mean & 39.64 (35.66) & 34.98 & 21.02 \\
\hline & & & SE \pm & $0.54(1.10)$ & 1.20 & 1.10 \\
\hline & & & $\mathrm{CD}$ at $5 \%$ & $1.54(3.11)$ & 3.42 & 3.11 \\
\hline & & & CV\% & $2.38(5.33)$ & 5.96 & 9.03 \\
\hline
\end{tabular}

Fig.1 Promising treatment combination for $\%$ contamination, $\%$ dead explants and $\%$ survival in nodal explants after sterilization with various concentrations of sterilizing agents for different time duration

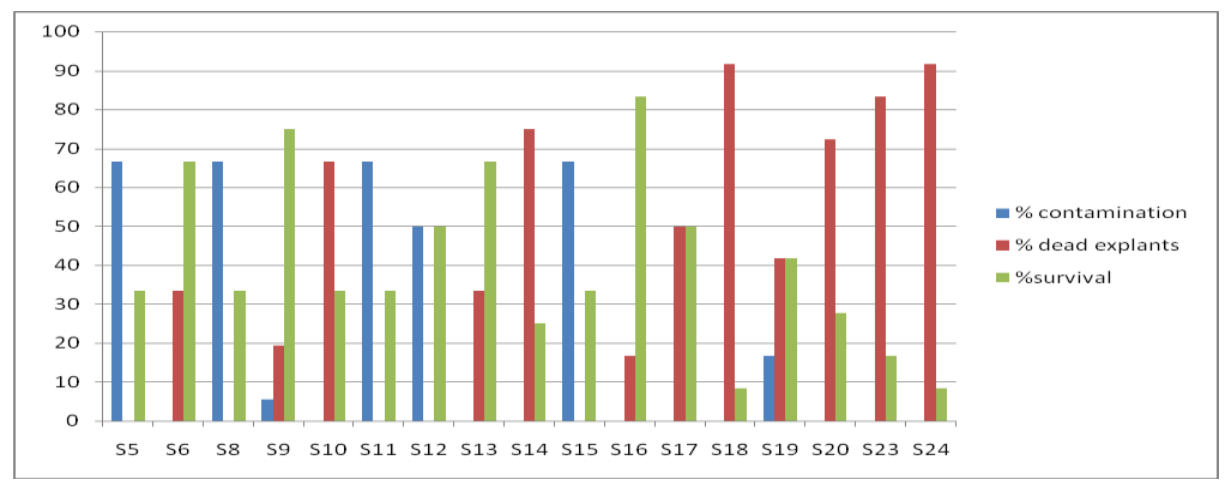

Fig.2 Promising treatment combination for $\%$ contamination, $\%$ dead explants and $\%$ survival in inter-node explants after sterilization with various concentrations of sterilizing agents for different time duration

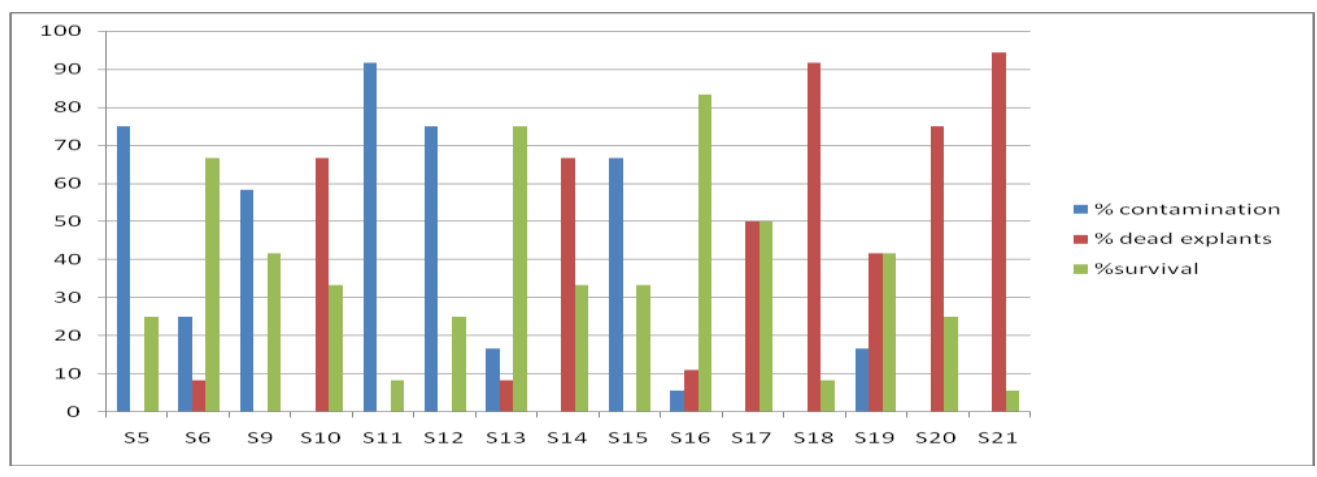


Plate.1 Standardizing efficient in vitro surface sterilization protocol through DDW + Bavistin $0.1 \%+\mathrm{HgCl} 20.1 \%+\mathrm{NaOCl} 1.0 \%(10+10+5+5)$ for inter node explant

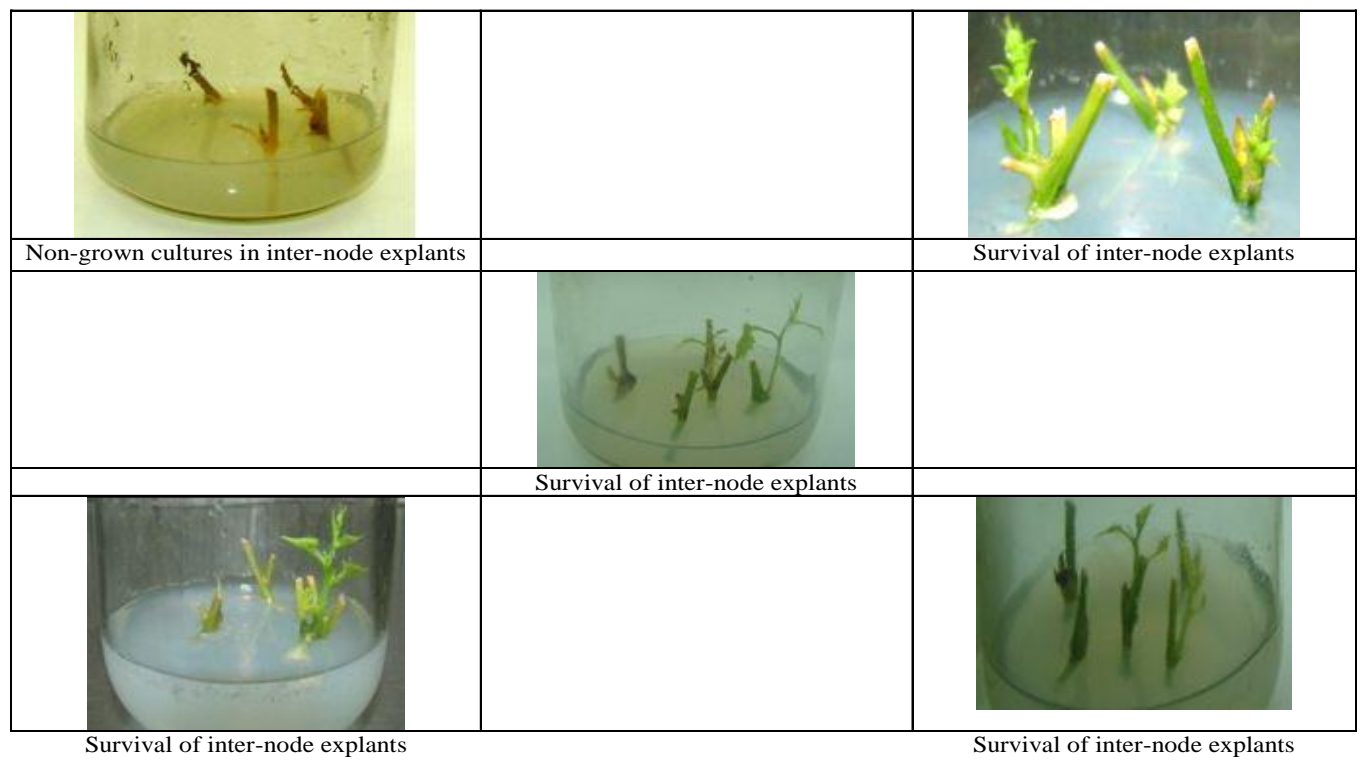

Plate.2 Standardizing efficient in vitro surface sterilization protocol through DDW + Bavistin $0.1 \%+\mathrm{HgCl} 20.1 \%+\mathrm{NaOCl} 1.0 \%(10+10+5+5)$ for nodal explant

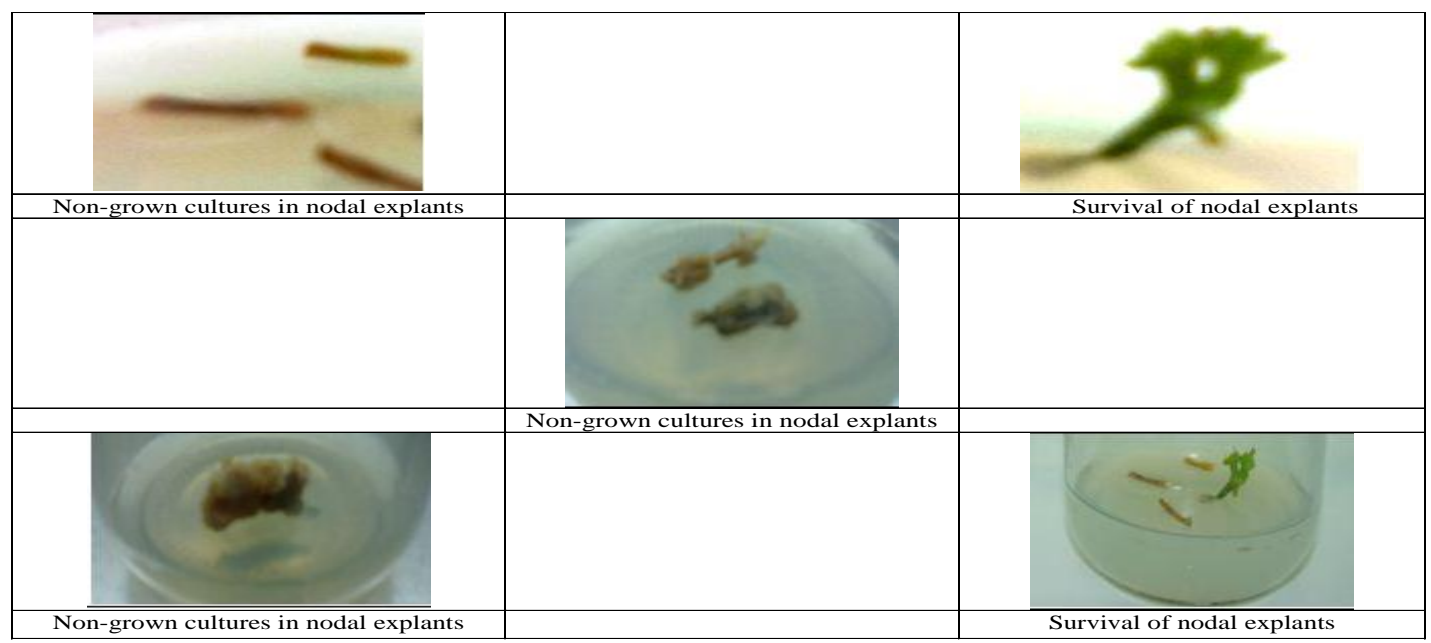

To evaluate the response of different treatment combinations, implantations of sterilized explants were done using without hormones MS medium and results showed that with increase of time the infection was decreases in both the sterilizing agents for all the two explants when sterilized explants individually or in combination of both sterilizing agents.

When $\mathrm{HgCl}_{2} \quad 0.1 \%$ was used alone, nodal segments and internodes explants recorded highest percentage $(66.67 \%)$ in treatment DDW + Bavistin $0.1 \%+\mathrm{HgCl}_{2} 0.1 \%$ 
$\left(10+10+10\right.$ minutes), $\mathrm{HgCl}_{2} 0.1 \%$ has been previously used for sterilization of different explants in different crops. Thakur et al., (2011) surface sterilized axillary buds of Momordica balsamina with $0.1 \%$ mercuric chloride solution for 7 minutes and Mustafa et al., (2013) surface sterilized explants of Kankoda internodes and nodes explants with $0.1 \% \mathrm{HgCl}_{2}$ for $7-8$ minutes.

When $\mathrm{NaOCl} 1.0 \%$ alone was used, the highest percentage of survival of cultures was recorded in treatment DDW + Bavistin 0.1\% $+\mathrm{NaOCl} 1.0 \%(10+10+7$ minutes $)$ with $75.00 \%$ and $41.67 \%$ by nodal segment explants and internode explants respectively. The $\mathrm{NaOCl} 1.0 \%$ has been extensively for sterilization of different explants with different time duration in different crops. Badoni and Chauhan (2010) developed in vitro sterilization protocol for micropropagation of potato cv. 'Kufri Himalini' by using sterilizing agent $1.0 \%$ $\mathrm{NaOCl}$ with 8 minutes time duration for explants sterilization.

For nodal segment explants, the survivals rates ranged from 0.0 to $83.33 \%$. The treatment DDW + Bavistin $0.1 \%+\mathrm{HgCl}_{2} 0.1$ $\%+\mathrm{NaOCl} 1.0 \%(10+10+5+5)$ recorded maximum survivals percentage $(83.33 \%)$ with $0.0 \%$ contamination and $16.67 \%$ nongrowing culture for nodal segment explants. For internode explants, the survival of cultures ranged from 0.0 to $83.33 \%$. The treatment DDW + Bavistin $0.1 \%+\mathrm{HgCl}_{2} 0.1$ $\%+\mathrm{NaOCl} 1.0 \%(10+10+5+5)$ recorded maximum survivals percentage $(83.33 \%)$ with $5.56 \%$ contamination and $11.33 \%$ nongrowing culture for internodes explants.

In treatments involving combination of $\mathrm{HgCl}_{2}$ and $\mathrm{NaOCl}$, the highest percentage of survivals of cultures were recorded in treatment i.e. DDW + Bavistin $0.1 \%+\mathrm{HgCl}_{2}$ $0.1 \%+\mathrm{NaOCl} 1.0 \%(10+10+5+5$ minutes $)$ with $83.33 \%$ for nodal segment explants as well as internode explants. The combinations of two different sterilizing agents for surface sterilization have been used in various reports. Miche and Balandreau (2001) analyzed the effect of combination of hydrogen peroxide and hypochlorite was used to surface sterilize rice seeds. Colgecen et al., (2011) analyzed the effects of $1.25 \%$ sodium hypochlorite and Plant Preservative Mixture (PPM) on surface sterilization in A. densiflora

\section{Suitable surface sterilization agents}

While comparing the effect of $\mathrm{HgCl}_{2}$ and $\mathrm{NaOCl}$ alone and in all possible combination with varying times, the treatment Bavistin $0.1 \%+\mathrm{HgCl}_{2} 0.1 \%+\mathrm{NaOCl} 1.0 \%$ $(10+10+5+5$ minutes time respectively) was always found better than any other treatments for suitable sterilization combination for both the explants used in this investigation.

This is the first report of successful sterilization and reduced contamination of explants from naturally field grown Kankoda (Momordica dioica Roxb., by using $\mathrm{HgCl}_{2}$ and $\mathrm{NaOCl}$ sterilizing agents in combination for standardizing efficient in vitro surface sterilization protocol. These results were found better for controlling the infection and it had not any adverse effect on explants even in long duration.

\section{References}

Badoni, Anoop and J. S. Chauhan (2010).In vitro Sterilization Protocol for Micropropagation of Solanum tuberosum cv. 'KufriHimalini' Academia Arena., 2(4) 24-27.

Bawara, B., Dixit M., Chauhan N. S., Dixit V. K. and Saraf D. K. (2010). Phytopharmacology of Momordica dioica Roxb. Ex. Wild; A Review. Int. J. Phytomedicine., 2:1-9. 
Bharathi, L. K., Naik, G., Singh, H. S. and Dora, D. K. (2007). Spine Gourd. In: Peter KV (ed.) Underutilized and Underexploited Horticultural Crops, New India Publishing, New Delhi, 289295.

Colgecen, H., U. Koca and G. Toker (2011) Influence of different sterilization methods on callus initiation and production of pigmented callus in Arnebia densiflora Ledeb. Turk $J$. Biol.,35 : 513-520.

Hooker, J. D. (1879). Theflora of British India, Vo. 2. L. Reeve. Co. Kent : England.

Miche Lucie and Jacques Balandreau (2001). Effects of Rice Seed Surface Sterilization with Hypochlorite on Inoculated Burkholderia vietnamiensis. Applied and Environmental Microbiology., 67(7): 3046-3052.

Mustafa, M. D., Swamy, T. N., Raju, S. and
Mohammad, S. K. P. (2013). Multiple shoot induction from the nodal cultures of teasle gourd (Momordica dioica (Roxb.). Intern. J. Biosciences., 3(2): 812.

Raj, N. M., Prasanna, K.P. and Peter, K.V. (1993).Momordica spp. In: Kallo, G., Bergh, B.O. (Eds.), Genetic Improvement of Vegetables Crops. Pergamon Press, Oxford, pp. 239-243.

Rashid, M. M. (1993). Shabji Bijgan, 2nd ed. Rashid Publishing House, Banani, Dhaka (in Bengali).

Thakur, G. S., Sharma, R., Sanodiya, B. S., Pandey, M., Baghel, R., Gupta, A., Prasad, G. B. K. S. and Bisen, P. S. (2011). High frequency in vitro shoot regeneration in Momordica balsamina, an important medicinal and nutritional plant. African J. Biotech., 10(70): 15808-15812.

\section{How to cite this article:}

Dodake, S. S., A. S. Jadhav, S. V. Pawar and Magar, N. M. 2020. Surface Sterilization Protocol for Nodal and Inter Node Explants of Kankoda (Momordica dioica Roxb.). Int.J.Curr.Microbiol.App.Sci. 9(12): 2907-2915. doi: https://doi.org/10.20546/ijcmas.2020.912.345 